\title{
Tampilan estrus kambing peranakan etawa dalam program sinkronisasi menggunakan prostaglandin F2 $\alpha$ yang diinjeksikan pada submukosa vulva
}

\author{
Sigit Prastowo ${ }^{1, *}$, Anna Yusanti ${ }^{1}$, Chairul Nisaa' ${ }^{1}$, Sunarto $^{1}$, Rini Widyastuti ${ }^{2,3}$ \\ ${ }^{1}$ Program Studi Peternakan, Fakultas Pertanian, Universitas Sebelas Maret, Surakarta, Jawa Tengah \\ ${ }^{2}$ Departemen Produksi Ternak, Fakultas Peternakan, Universitas Padjajaran, Sumedang, Jawa Barat \\ ${ }^{3}$ Program Studi Kedokteran Hewan, Fakultas Kedokteran, Universitas Padjadjaran, Sumedang, Jawa Barat
}

\begin{abstract}
ABSTRAK: Penelitian ini bertujuan membandingkan tampilan estrus kambing Peranakan Etawa (PE) dalam program sinkronisasi estrus menggunakan hormon prostaglandin F2-alfa (PGF2 $\alpha$ ) yang diinjeksikan pada submukosa vulva (SMV). Sebanyak 10 ekor kambing PE berumur 2,5 tahun dan telah mengalami 2 kali partus digunakan sebagai unit percobaan. Injeksi PGF2 $\alpha$ secara SMV pada P1 = dosis $0,1578 \mathrm{mg} / \mathrm{ml}(\mathrm{n}=5)$ dan $\mathrm{P} 2=$ dosis $0,0789 \mathrm{mg} / \mathrm{ml}(\mathrm{n}=5)$ menggunakan dosis ganda dengan interval injeksi 11 hari. Tampilan estrus diamati dan diukur menggunakan Draminski Heat Estrous Detector (DHED) mulai 24 jam setelah injeksi kedua setiap 8 jam hingga tanda estrus menghilang. Nilai hambatan arus listrik (HL) yang ditampilkan oleh DHED selama pengamatan digunakan untuk melihat awal, puncak dan akhir estrus. Hasil pengamatan menunjukkan bahwa nilai HL puncak estrus berbeda dengan awal dan akhir estrus ( $<<0,05)$ pada setiap P1 dan P2. Rata-rata

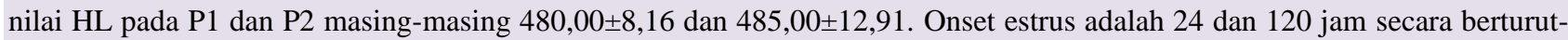
turut pada P1 dan P2 dan lama estrus adalah 44,00 dan 43,50 jam. Injeksi hormon PGF2 $\alpha$ pada kambing PE secara SMW mampu memperlihatkan tampilan estrus dengan onset lebih lama pada dosis hormon yang lebih rendah.
\end{abstract}

Kata kunci:

estrus, sinkronisasi, prostaglandin F2-alfa, kambing Peranakan Etawa.

\section{- PENDAHULUAN}

Salah satu upaya untuk mengatasi kesulitan deteksi estrus pada kambing adalah dengan menerapkan sinkronisasi estrus (Chao et al., 2008; Dogan et al., 2005), sehingga perkawinan baik dengan inseminasi buatan atau secara alami dapat dilakukan secara serentak (Karikari et al., 2009). Sinkronisasi estrus dapat dilakukan dengan injeksi hormon prostaglandin F2-alfa (PGF2 $\alpha$ ) (Wildeus, 2000) secara intramuskuler ataupun submukosa vulva (SMV). Injeksi pada SMV memiliki kelebihan dimana hormon lebih cepat mencapai target organ yaitu ovarium (Ilham et al., 2016) dan lebih efisien. Penelitian ini dilakukan untuk mengevaluasi tampilan estrus kambing PE dalam program sinkronisasi estrus menggunakan hormon PGF2 $\alpha$ secara SMV.

\section{- MATERI DAN METODE}

Penelitian ini menggunakan 10 ekor kambing PE betina berumur 2,5 tahun, dengan berat badan 40-50kg, tidak bunting dan telah mengalami 2 kali partus. Kambing dipelihara dengan pemberian pakan dua kali sehari. Komposisi pakan terdiri dari wheat brand, kedelai, ampas tahu, onggok dan hijauan. Air diberikan secara adlibithum. Sinkronisasi estrus dilakukan dengan injeksi PGF2 $\alpha$ (Lutaprost@ 250, mengandung cloprostenol sodium) secara
SMV pada labia vulva. Perlakuan terbagi dalam dua kelompok injeksi PGF2 $\alpha$ secara SMV yaitu kelompok P1 dosis 0,6 ml (0,1578 $\mathrm{mg}, \mathrm{n}=5)$, dan kelompok P2 dosis 0,3 $\mathrm{ml} \quad(0,0789 \mathrm{mg}, \mathrm{n}=5)$. Metode sinkronisasi estrus menggunakan dosis ganda dengan interval injeksi 11 hari (Prastowo et al., 2010).

Pengamatan estrus dilakukan 24 jam pascainjeksi dosis kedua menggunakan Draminski heat estrous detector (DHED). Pemeriksaan dilakukan setiap 8 jam sekali sampai tanda-tanda estrus menghilang. Parameter tampilan estrus adalah daya hambat listrik (HL), onset estrus dan lama estrus (jam). Onset estrus dihitung dari awal sampai puncak estrus, sedangkan lama estrus dihitung sejak tanda estrus muncul sampai menghilang. Nilai HL kemudian digunakan sebagai tolok ukur dalam menentukan tahapan estrus yaitu: awal, puncak dan akhir estrus. Data yang didapat kemudian dianalisis secara statistik menggunakan uji ANOVA. Ratarata onset dan lama estrus antar kelompok perlakuan dibandingkan dengan $t$-test, dalam penelitian ini beda nyata antar perlakuan apabila nilai $\mathrm{p}<0,05$.

\footnotetext{
Diterima: 14-02-2019 | Direvisi: 15-03-2019 | Disetujui: 25-03-2019

(c) 2019 CC-BY-SA. Ini adalah artikel Open Access yang didistribusikan berdasarkan ketentuan dari Creative Commons Attribution ShareAlike 4.0 International License (https://creativecommons.org/licenses/by-sa/4.0/).
} 


\section{- HASIL DAN PEMBAHASAN}

Pengamatan tampilan estrus kambing PE menggunakan DHED menunjukkan nilai HL tinggi saat awal estrus, turun pada puncak dan naik lagi pada akhir estrus di kedua perlakuan (Gambar 1). Nilai HL terendah merupakan

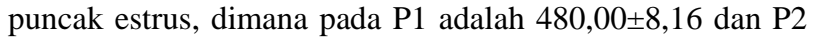
adalah $485,00 \pm 12,91$ serta berbeda secara nyata diantara masing-masing pada tahapan awal dan akhir estrus $(\mathrm{p}<0,05)$ (Tabel 1). Onset estrus P1 dibandingkan P2 berbeda nyata $(\mathrm{p}<0,05)$ masing-masing 20 dan 120 jam, sedangkan lama estrus pada P1 dan P2 tidak berbeda, masing-masing 44,00 dan 43,50 jam.

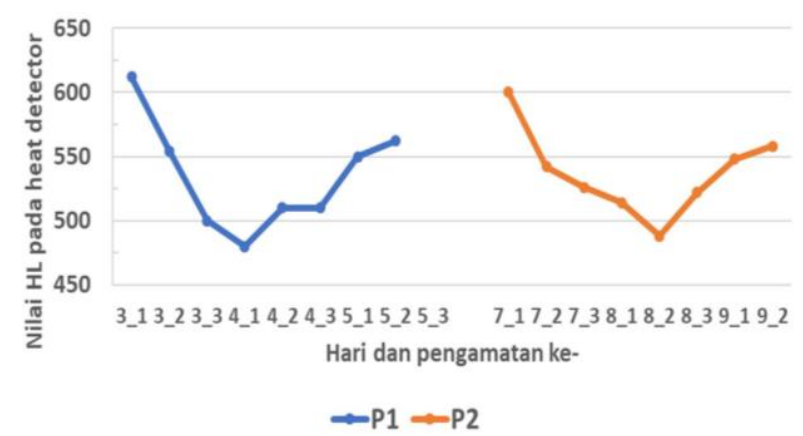

Gambar 1 Nilai HL lendir pada DHED kambing PE selama pengamatan estrus pascainjeksi PGF2 $\alpha$ secara SMV.

Tabel 1 Perbandingan nilai HL pada DHED kambing PE pada awal, puncak dan akhir estrus pascainjeksi PGF2 $\alpha$ secara SMV.

\begin{tabular}{llll}
\hline \multirow{2}{*}{ Perlakuan } & \multicolumn{3}{c}{ Nilai HL heat estrous detector } \\
\cline { 2 - 4 } & Awal & \multicolumn{1}{c}{ Puncak } & Akhir \\
\hline P1 & $552,50 \pm 12,58^{\text {a }}$ & $480,00 \pm 8,16^{\mathrm{b}}$ & $555,00 \pm 10,00^{\mathrm{a}}$ \\
P2 & $565,00 \pm 12,91^{\text {a }}$ & $485,00 \pm 12,91^{\mathrm{b}}$ & $557,50 \pm 17,08^{\mathrm{a}}$ \\
\hline
\end{tabular}

Superskrip pada baris yang sama menunjukan beda nyata $(\mathrm{p}<0,05)$

Hormon PGF2 $\alpha$ merupakan hormon luteolitik (Senger, 2005) yang bekerja sebagai vasokonstriktor pada pembuluh darah untuk menghambatan aliran darah ke corpus luteum (CL), sehingga mengakibatkan CL menjadi regresi (Hafez and Hafez, 2000). Injeksi kedua dosis berbeda pada kelompok P1 dan P2 dalam penelitian ini mampu menggertak estrus pada kambing PE. Hal ini berarti penyuntikan PGF2 $\alpha$ secara SMV dapat melisiskan CL yang kemudian menstimulasi rangkaian sekresi hormon reproduksi dan berakhir pada timbulnya estrus (Senger, 2005).

Kelompok perlakuan P2 dengan dosis PGF2 $\alpha$ yang lebih sedikit, memperlihatkan onset estrus yang lebih lama dicapai dibandingkan dengan P1. Hal ini dapat dijelaskan karena dosis hormon yang lebih sedikit memerlukan waktu yang lebih lama untuk dapat melisis CL. Lama estrus kambing PE dalam penelitian ini lebih panjang dibanding penelitian sebelumnya yaitu 33-35 jam pada kambing kacang (Prastowo et al., 2010), dan 26-35 jam pada kambing Toggenburg, Alpine dan Saanen (Esteves et al., 2013). Perbedaan lama estrus dapat disebabkan oleh perbedaan bangsa ternak, kecukupan nutrisi dalam pakan dan cara pengamatan estrus.

\section{- SIMPULAN}

Injeksi hormon PGF2 $\alpha$ secara SMV pada kambing PE dapat menginduksi terjadinya estrus. Meskipun demikian, injeksi hormon dengan dosis yang lebih sedikit dapat memperlambat onset dari estrus.

\section{- INFORMASI PENULIS}

Penulis untuk Korespondensi

*SP: prastowo@staff.uns.ac.id

Program Studi Peternakan, Fakultas Pertanian,

Universitas Sebelas Maret, Surakarta, Jawa Tengah, INDONESIA

Kontribusi penulis

SP dan RW merencanakan penelitian dan menulis naskah, AY dan $\mathrm{CH}$ melakukan penelitian dan analisis data, $\mathrm{S}$ mengevaluasi hasil penelitian. Semua penulis menyetujui versi final naskah publikasi.

\section{- PUSTAKA ACUAN}

Chao LM, Takayama K, Nakanishi Y, Hamana K, Takagi M, Kubota C, Kojima T. 2008. Luteal lifespan and fertility after estrus synchronization in goats. Journal of veterinary science. 9(1):95-101.

Dogan I, Nur Z, Gunay U, Sagirkaya H, Soylu MK, Sonmez C. 2005. Estrous synchronization during the natural breeding season in Anatolian black does. Vet Med-Czech. 50(1):33-8.

Esteves LV, Brandão FZ, Cruz RC, Souza JM, Oba E, Facó O, Fonseca JF. 2013. Reproductive parameters of dairy goats submitted to estrus synchronization with prostaglandin $\mathrm{F} 2 \alpha$ associated or not to hCG at estrous onset. Arquivo Brasileiro de Medicina Veterinária e Zootecnia. 65(6):1585-92.

Hafez ESE, Hafez B. 2000. Reproduction in Farm Animal, 7th ed. Lea and Febiger, Philadelphia.

Ilham F, Dako S, Rachman A, Hulubangga Y. 2016. Onset dan lama estrus kambing kacang yang diinjeksi prostaglandin F2 $\alpha$ pada submukosa vulva. Seminar Nasional Peternakan 2. Fakultas Peternakan Universitas Hasanuddin Makasar. 25 Agustus 2016. 23-27.

Karikari PK, Blasu EY, Osafo EL. 2009. Reproductive response of West African dwarf does to prostaglandin administration. World Applied Sciences Journal. 6(4):542-5.

Prastowo S, Ratriyanto A, Sudiyono S, Sunarto S. 2010. Respon birahi kambing peranakan etawa betina yang mendapat suplementasi pakan urea molases mineral anti parasit blok dalam program sinkronisasi estrus menggunakan hormon prostaglandin F2 $\alpha$. Caraka Tani: Journal of Sustainable Agriculture. 25(2):55-59.

Senger P. 2005. Pathway to Pregnancy and Parturition, 2nd ed. Pullman, Washington.

Wildeus S. 2000. Current concepts in synchronization of estrus: Sheep and goats. J. Anim Sci. 77: 1-14. 